\title{
Study on the Normalization of "Studies on the Theoretical and Practical Issues of Party Building" Learning and Education in Private Colleges
}

\author{
Qingtao Guan, Zlongling Tong \\ Changchun Sci-Tech University, Changchun, Jilin, 130600
}

Keywords: normalization; studies on the theoretical and practical issues of party building; private colleges

\begin{abstract}
Private colleges are an important part of China's higher education and bear the heavy responsibility of cultivating socialist builders and successors. To this end, it is necessary to adhere to the direction of socialist education, combine the characteristics of schools and the actual work, strengthen party building work, carry out "Studies on the theoretical and practical issues of party building" learning education in different categories, and consolidate the foundation of the organization; The aim is to increase the awareness of "learning" and "doing" so that the true knowledge is understood and the brains are involved. The study and education of "Studies on the theoretical and practical issues of party building" implemented play an exemplary vanguard role in their respective positions.
\end{abstract}

\section{Introduction}

In view of the status quo of party members in private universities, the study and education of "Studies on the theoretical and practical issues of party building" is promoted in different categories and levels, so that the majority of party members can respect party constitutions and abide by party rules and regulations, and use Xi Jinping's socialist ideology with Chinese characteristics in a new era to arm them. The party is the fundamental task for the majority of party members and cadres to keep in mind the purpose of the party, never forget the beginning of the heart, strictly meet the standards of party members, and play a vanguard role in daily work.

\section{The Importance of the Institutionalization of Learning and Education}

In order to strengthen the party's ideological development, since the party's 18th National Congress, the central government has successively carried out mass line education practice activities, "three strict and three real" thematic education, and "Studies on the theoretical and practical issues of party building" learning and education [1]. The Chinese Communist Party, the world's largest ruling party, has gone through 96 years. It is a world-class challenge how to let the majority of party members not forget the beginning of the mind, keep in mind the purpose, and rejuvenate. The study and education of "Studies on the theoretical and practical issues of party building” is an important starting point for promoting comprehensive and strict management of the party and extending it to grass-roots units. It aims at solving outstanding problems in the party members' ideology, organization, style, and discipline. This will give full play to the party's role as a fighting fortress and the vanguard and exemplary role of party members. To promote the institutionalization of study and education on "Studies on the theoretical and practical issues of party building", it is necessary to use party rules and regulations to regulate the behavior of party organizations and party members, and use $\mathrm{Xi}$ Jinping's socialist ideology with Chinese characteristics to arm their minds, guide practice, and promote work. , Integrate learning and education into the daily routine and grasping it regularly, so as to learn to think and practice, and to integrate knowledge and practice. It truly reflects political eligibility, eligibility for discipline, quality of ethics, and fulfillment of roles. 


\section{Status of Learning and Education on "Studies on the theoretical and practical issues of party building”}

Implementing the party's education policy and firmly grasping the direction of socialist education, private Colleges are in the same way as public Colleges, in order to train qualified socialist builders with Chinese characteristics and reliable successors. In private Colleges to promote the "Studies on the theoretical and practical issues of party building" study and education normalized institutionalization, and effectively strengthen the party's construction, the implementation of the party's education policy, adhere to the direction of socialist education is of great significance [2]. By carrying out "Studies on the theoretical and practical issues of party building" study and education, it is beneficial to strengthen the party's political core role and the role of supervision and guarantee in private universities. However, the composition of party members in private Colleges is complex and the party members' teachers are more mobile. There are blind spots in the management of mobile party members. The college students are very active in joining the party organization. However, there are fewer indicators of student party membership and the opportunities for organizations to absorb are not improving steadily. The education of party members is not enough. The understanding of the importance of the party's activities is not in place. The education and management of party members is relatively loose. Promote the institutionalization of study and education in the "Studies on the Theory and Practical Issues of Party Building", and use the party rules and regulations as the basic motive force to strengthen the concept of Party spirit, and study the spirit of Xi Jinping's series of important speeches and the new idea of governing the country The new strategy is a required course for improving self-cultivation. This is a powerful solution to the problem of private universities building ideologically.

\section{Promote the "Studies on the theoretical and practical issues of party building"}

Normalizing the normalized inner-party life is the symbol and guarantee of the party's combat effectiveness. It is also an important condition for promoting the normalization and institutionalization of the "Studies on the Theory and Practical Issues of Party Building". As the saying goes, the nine-story platform started from the land. The normalization of study and education on "Studies on the theoretical and practical issues of party building" in Colleges must be a good tradition in party building work, that is, the standardization of organizational life. Since the founding of the Communist Party of China, in order to build a learning-oriented, service-oriented, innovative Marxist political party, it has explored and accumulated many valuable and useful traditional practices to ensure the standardization of the Party's organizational life. The "three sessions and one lesson" system is one of many valuable traditional practices. The "three sessions and one lesson" system is the convening of the branch party members' assembly, the branch committee, and the party group meeting in the designated period to make party classes on time [3]. The "three sessions and one lesson" system is an important system to improve the party's organizational life and strengthen the education of party members. Under the new situation, the Colleges adhere to the "three sessions and one lesson" system, which can make the "Studies on the theoretical and practical issues of party building" study and education run through them, and constantly enhance the party members' concept of party spirit, prompting university members to consciously play a pioneering role. Model role, make qualified party members. In order to promote the normalization of study and education on "Studies on the theoretical and practical issues of party building", Colleges need to pay great attention to the use of basic forms such as the "three sessions and one lesson" and give full play to the methods of party members' meetings, branch committees, party committee meetings, and party lessons. Different roles highlight the characteristics of normal education. In the party members' conference, thematic discussions were conducted in conjunction with the party's latest conference spirit. In the branch committees, on the basis of extensive solicitation of opinions, talks, and questions, we developed a branch learning and education program and integrated the "studies on the theoretical and practical issues of party building" education into our daily work. In the party group meetings, according to the plan of the committee, 
learning groups, seminars, symposiums, etc. are organized to organize the party group members to study intensively and to discuss the important spirits of the party Central Committee, the provincial party committee, the municipal party committee, and the school party committee. Talk about feelings, talk about it. In the party class, with the aim of strengthening the party members' consciousness and ideals and beliefs, they passed the latest theoretical results of Marxism in China and the spirit of General Secretary Xi Jinping's series of speeches, and passed party branch secretaries, party branch members, and heads of discipline groups (heads of teaching and research offices). We will teach the topic party class or the micro party class to help the party members teachers understand the spirit, quasi-direction, and firm belief, and promote the daily learning and education of "Studies on the Theory and Practical Issues of Party Building". In addition, we must earnestly implement basic systems such as the organization of life meetings, democratic life meetings, talks within the party, democratic evaluation of party members, and regular analysis of the party members' party spirit [4]. In these activities, we must uphold high standards and truly organize and organize life seriously, and we must Craftsmanship, skill, and long-term efforts have made Party members and teachers red-faced and sweating during these activities, stimulating the popularity of Party members in maintaining advanced nature and guiding all Party members and teachers to consciously commit themselves to "Studies on the theoretical and practical issues of party building." In learning and education, we must increase political awareness, awareness of the overall situation, core awareness, and read awareness, be fearful of the facts, be reprimanded, and behave. At any time, discipline and rules are at the forefront, and we must adhere to the bottom line. Being a man, he is a clean and clerk, and thus constantly has new ideas in his thoughts, and constantly has new consciousness in his actions.

Innovation is the source of vitality; carrier is the starting point for work. A good activity carrier is conducive to broadening ideas and improving the effectiveness of activities. To carry out "Studies on the theoretical and practical issues of party building" education in Colleges, we must choose the carrier, enrich the forms of learning and education, and highlight the carrier's "human nature" and adherence to the "effectiveness" of the carrier. "On the theory and practical issues of party building," the contents and methods of learning education and the goals and tasks are integrated into the concrete carriers, and the intangibles are tangible and abstract to concrete. "Learning, education, and experience can be seen in education, and the ideas, wisdom, and strength of college teachers' party members can be effectively brought together to promote the normal learning and education of Colleges "the questions and practice issues of party building". Change. In Colleges to carry out "Studies on the theoretical and practical issues of party building" study and education, learning to discuss the carrier to ground gas, we must grasp the "living" principle. To ensure that the "Studies on the Theory and Practical Issues of Party Building" learning and education blossoms and achieves the desired goals, we need to work hard on the word "living" and read the words "living" to learn and do well. According to the different characteristics of party members as leading cadres, party members, and student party members, it is necessary to continuously innovate in learning and discussions, such as setting up "cultural forums" and "communist party reading conferences" and other characteristic carriers for learning exchanges; adherence to the combination of individual studies and collective learning, such as Lectures, questions and answers, special topics to discuss "study, training, match" action, in-depth implementation of "one sentence promise" "the party is on the side" "Party members learning" "Party members in activities" "Party members in action" to ensure " "Studies on the effects of education and practice issues of party building" The effect of learning and education; learning and discussion can be carried out on the basis of "the Party's League Day Activity”, and actively promote the activities of Party members' educational activities, party members' day of contact, party affairs, and grassroots democratic day. Forms can also be based on the theme of learning advanced models, with the people around them talking about the things around them and the things around them saying that everyone understands them, so that in the form of people's loved ones, in the form of advanced learning among the party members, advanced, advanced, and The advanced upsurge led the party members to use advanced models as benchmarks for the party members to Unknowingly school knowledge, learn the rules, understand 
the rules.

Comrade Xi Jinping pointed out: "The party must manage the party and strictly administer the party, must have a strong system as a guarantee. Fully and strictly manage the party, we must adhere to the close connection between the ideological party building and the system governance party, all-round system cage, more Use the system to govern the party, the power, and the government.”. Therefore, strengthening institutional development, especially the construction of safeguard mechanisms, has become an important part of promoting the study and education of Colleges on the "theory and practical issues of party building". The construction of a comprehensive "Studies on the theoretical and practical issues of party building" education and education guarantee system will help give full play to the system's "conducting baton" and "spelling spell" and make the university "Studies on the theoretical and practical issues of party building" "Education education has goals, stress, motivation, and guarantees; it helps all party members and staff to tighten the "Studies on the theoretical and practical issues of party building" learning and education at the same time, and prevents learning and education from going through the field and a gust of wind [5]. The party organizations at all levels in the university and all party members and cadres have standardized norms and have a cage of power. Comrade Xi Jinping also emphasized in his important instruction on the "Studies on the theoretical and practical issues of party building" study: We must seriously address the political life in the party in light of new situations and new issues, fill in shortcomings in the system through reform and innovation, and truly make the party The organizational life and the education and management of the party members are strictly enforced and implemented. According to Xi Jinping's emphasis on "repairing the shortcomings in the party's internal system" and using the spirit of nailing nails for a long time, we must comprehensively implement policies, implement responsibilities, grasp supervision and evaluation, grasp job evaluation, and pay attention to the implementation of funds so as to truly make Colleges "Studies on the theoretical and practical issues of party building" study and education is focused on the daily, strict and regular, so that the built-up mechanism is truly valuable and effective. Specifically, in order to promote the normalization of "Studies on the theoretical and practical issues of party building" in Colleges, we must establish responsibility guarantees, supervision and protection,

\section{Acknowledgements}

The Changchun Sci-Tech University, Startup Fund Project "On the Path of the Normalization of "studies on the theoretical and practical issues of party building" Learning and Education in Private Colleges"

\section{References}

[1] Central Committee of the Communist Party of China. On Strengthening and Improving Ideological and Political Work in Colleges in the New Situation [N]. China Education News, 2017 2 - 28(1)

[2] Huang Jianhui. To carry out "two studies and one" study and education, and effectively promote the comprehensive management of the party [J]. Xinjiang Social Science Forum, 2016, 4

[3] Wang Fang. Deeply carry out "two studies and one" study and education for the reform and development of Colleges [J]. Beijing Education, 2016, 6

[4] Li Du. Solidly carry out "two studies and one" learning and education [J]. Theory and Contemporary, 2016, 4

[5] Cao Ruiming. The innovation of party building work in private Colleges [J]. Journal of Zhejiang Shuren University, 2014,6 